Resumen por el autor, T. H. Bast

Varios tipos de amitosis en las células óseas.

El estudio de las células óseas ha demostrado que la amitosis es el método normal y exclusivo de multiplicación de dichos elementos. La amitosis en el hueso constituye dos tipos, determinados por la forma del núcleo en vias de división y por la función y posición de los centrosomas. En el primer tipe el núcleo presenta forma de bizcocho y los centrosomas están situados en cualquiera de sus polos. En el segundo tipo el núcleo presenta forma de herradura y los centrosomas, que no se hand separado, yacen en una escotadura de dicho órgano celular. La existencia de masas de citoplasma casi separadas de las células principales indica que también tiene lugar la fragmentación de la célula. Una revisión de la literatura sobre la amitosis, junto con observaciones en otros tejidos, demuestra que existe otro tipo de amitosis en el cual una estructura en forma de placa indica el plano de la división nuclear. Los centrosomas de este tipo parecen carecer de función o pueden faltar por completo. La literatura sobre esta cuestión puede clasificarse según las diversas teorías de la amitosis que han sido propuestas hasta la fecha.

Translation by Jose F. Nonjdez

Cornell Medical College, New York 


\title{
VARIOUS TYPES OF AMITOSIS IN BONE CELLS
}

\author{
T. H. BAST \\ Anatomical Laboratory, University of Wisconsin \\ TWO TEXT FIGURES AND ONE PLATE (TWELVE FIGURES)
}

\section{INTRODUCTION}

After seeing some of my preparations, Dr. H. E. Jordan suggested to me that a more extended study might add something to our knowledge of amitosis in the growth and repair of the living mechanism. Upon careful examination of the preparations of bone cells, many stages of nuclear and cells division were noted. These observations showed that amitosis was the only method of division present. Other preparations were made from various ages of bone and from various animals. In these preparations all stages of amitotic division were present, but not a single mitotic figure could be found. In the light of the recent discussions on the prevalency, cause, and significance of amitosis, these observations are very suggestive, especially since the various stages of division are so numerous and clear. Of greater import, however, for our knowledge of cell division is the observation that in the multiplication of bone cells two types of amitosis occur, and that these types are not only due to the difference in the form of the dividing nuclei, but that the form of division is also determined by the activity and position of the centrosomes.

\section{MATERIAI AND TECHNIQUE}

The parietal bones of new born to three-weeks-old rats and the nasal bones, especially the ethmoid of the dog and rabbit, served as material for this study. Small pieces of bone are fixed in 95 per cent alcohol. The technique for their further preparation is the same as that described in my previous paper. 
Staining with iron hematoxylin was attempted, but without success. It was hoped that a clearer picture of the centrosomes would be obtained by this method, but the process corroded and stained the bone to such an extent that the details were obscured. Centrosomes can be detected with considerable clearness in gentian-violet preparations, but they are not distinct in all cases.

Considerable difficulty was at first encountered in obtaining permanent mounts. Gentian violet has a tendency to fade if mounted in balsam. Quite satisfactory results are obtained, however, by mounting overstained preparations in balsam and exposing them to light for a month or more. In ordinary preparations the nuclear stain was well preserved, but the cytoplasmic coloration disappeared perceptibly. After some experimentation it was found that almost perfect preservation can be obtained in Canada balsam by observing the following precautions: 1) After dehydrating in absolute alcohol, wash in several changes of benzol to remove all traces of alcohol. 2) Mount in warm, thick, neutral balsam. I have several slides, prepared according to this method over a year ago, in which the staining is still almost perfect. It may be of interest to note that preparations can be preserved in benzol indefinitely, even in strong light, without fading.

\section{DESCRIPTION}

Ratio of dividing to non-dividing cells

In order to obtain a somewhat accurate idea of the ratio of dividing to non-dividing cells, it is necessary to consider both young and old bone. This study, however, yields only generalized results, since the ratio shows considerable range of variation in different bones and in different regions of the same bone. Thus in the ethmoid bone of an adult dog the greater number of cells show no signs of division; in some fields none, while in others as many as one cell out of every three are in some stage of division. In the parietal bone of a twenty-one-day rat a considerable range of cell age is encountered, and it shows that divid- 
ing cells are more abundant in the younger than in the older area, yet in both regions the proportion is quite variable. This variability is also obvious in very young bone, although in it most cells are in some stage of proliferation (figs. 10 and 12). (See also figs. 2 and 6 of my previous article on bone cells.) Apparently this dividing process is a periodic affair, as shown by the fact that in a given region, especially in young bone, all the cells are practically in the same stage of proliferation. Because of this variability, the exact ratio of dividing to non-dividing cells cannot be given. It may be stated, however, that in young bone such as is found in one-to twenty-day-old rats, proliferating cells are so abundant that almost any stage of division can be found without difficulty. In older bone this occurs with less frequency.

\section{Nature of cell division}

In my previous paper it was shown that all cell division in bone is accomplished by amitosis. This requires little further description but can readily be noted in the accompanying figures (pl. 1). There is no sign of chromatin rearrangement nor of the disappearance of the nuclear wall in any case. At any stage the chromatin of the nucleus is grouped in small masses and irregularly distributed with a slight condensation at the periphery. This structure should be compared with the nucleus of a nondividing cell as shown in figure 1.

\section{Types of amitosis}

It is a very striking phenomenon that among dividing bone cells two nuclear forms occur. In the one case the nucleus is dumb-bell shaped, while in the other it is horseshoe-like in form. Amitotic cells with the dumb-bell nuclei are not very common and usually occur in old bone, but may occasionally be seen in young bone also. Three stages of dumb-bell amitosis are shown in figures 2,3 , and 4 . In figures 2 and 3 the two ends of the nucleus seem to be drawn in opposite directions, causing a rarefaction of the nucleoplasm in the middle which is followed by a constriction. The arrangement of the nuclear chromatin 
is not different from that of the non-dividing nucleus as shown in figure 1. Figure 4 shows the nucleus completely divided. The two halves have moved in opposite directions and the cytoplasm at the plane of nuclear division is so constricted that the resemblance to true cell division is complete except for a narrow cytoplasmic connection. Whether such cytoplasmic connections always remain as narrow canalicular processes or sometimes divide completely to form two separate cells, I am unable to say. Certain it is that some cytoplasmic processes which are continuous with similar processes of sister cells are completely pinched off in the process of growth and become separated by bone matrix, but whether all of the processes are ever thus separated to form non-communicating cells, I am unable to say, since I have observed no such cases.

Another important structure, the centrosome, should be noted in connection with the dumb-bell-shaped nucleus. Centrosomes are not often clearly seen in dividing bone cells. This is especially true for this type of amitotic division because it is not frequently found. Figure 2 shows a cell in which the centrosomes are unmistakably distinct. They are placed in the cytoplasm at the two ends of the dumb-bell-shaped nucleus. The centriole within one centrosome is somewhat elongated, but the entire length was not visible in a single plane of focus. It appeared to lie at an angle of about $45^{\circ}$ with this plane. Figure 2 shows the centriole as it appeared under a shifting focus. While in cells of this type centrosomes are not commonly seen, the centrosomes of this particular cell were so unmistakable, and duplicated so perfectly other less distinct observations, that it warrants the conclusion that this position of the centrosome is the rule for the dumb-bell type of amitosis.

By far the majority of the cells divide by the horseshoe type of amitosis. In young bone almost any stage of this type of cell division can be found, and one may often find every cell in some stage of division. It usually happens, however, that in a given field or even in a given parietal bone all dividing cells have approximately the same nuclear form. The various stages in the horseshoe type of amitosis are shown in figures 4 to 12 . 
Clear pictures of centrosomes are fairly common, but in this connection it should be remembered that a very large number of this type of cells are available from which to pick good stages. That many of the cells do not show centrosomes clearly can be explained by the fact that they may be obscured by other bone cells lying at a higher or lower level; or the cell may be so oriented that its own nucleus is the obscuring factor; or again in many cases protoplasmic processes viewed on end appear as deeply stained dots easily confused with granules and often obscuring the centrosome; or, finally, indistinct vacuoles lying in the granular cytoplasm appear so much like centrosomes that the picture is confusing. Thus in many cells the centrosomes are present, but cannot be cited as typical because of these obscuring structures. The various possibilities of the horseshoe type of amitosis are shown in figures 5 to 12 . Figure 5 is a typical example of a cell in the early stages. At first the nucleus is kidney shaped with the centrosomes in the position of the hilum. The bending of the nucleus then increases so as to produce the horseshoe shape. The centrosomes do not migrate apart as they do in the dumb-bell-shaped nucleus, but remain in the concavity. It seems that the nucleus changes in such a way that each part of it remains as near the centrosome as possible. Often the two ends of the nucleus encircle the centrosomes to such an extent that they touch each other or even overlap. In this case, when viewed from the side the nucleus is ring-shaped with the centrosomes enclosed within.

A dividing nucleus is shown in figure 6. Division here is different from that in the dumb-bell type. Instead of becoming elongated, the nucleus is pinched in two without any perceptible moving apart of the daughter nuclei. The resulting kidneyshaped nuclei then separate a little (fig. 7) and the cell engages in cytoplasmic constriction (fig. 8). Later stages in cytoplasmic constriction are seen in figures 10 and 12.

Nuclear division does not always result in only two nuclei, but nucleic horseshoes sometimes split into three, four, or more daughter nuclei (figs. 9 and 11). Multinuclear cells are not numerous and are found in young bone. Whether such cells 
really undergo cytoplasmic division cannot be stated with certainty, but pictures like figures 10 and 12 afford strong evidence that they do. That the cells in figure 10 are the product of a trinuclear cell can hardly be questioned. The cells in figure 12 may have resulted from two mother cells, but it is highly probable that they are the product of a tetranucleated mother cell.

The centrosomes in these multinucleated cells always lie in the center of the ring of nuclei. In such cells a variable number of centrioles are present. The number of these usually corresponds to the number of nuclei, but sometimes the number is considerably larger. This structure seems to correspond to the pluricorpuscular centrosomes which Jordan observed in polykeryocytes.

It is a striking fact that in polynuclear cells the cytoplasm is very abundant (figs. 9 and 11). It may be that this large amount of cytoplasm is a factor which determines the number of daughter nuclei into which a given nucleus shall divide.

Another structure which is common is the non-nucleated mass of protoplasm almost completely separated from the cell. Two such masses are shown in figure 2 and smaller masses in figures 7,8 , and 9 . In rare cases small bits of nucleoplasm are included therein, as was indicated in my previous paper. Such structures are indicative of cytoplasmic separation without nuclear involvement.

\section{SIGNIFICANCE OF AMITOSIS}

The place of amitosis in the vital mechanism is a question which has been under critical discussion since Strasburger ('82) and Waldeyer ('88) advanced the view that amitosis in vertebrates was a survival of a primitive process. Since then many theories have been presented, some of which consider amitosis as a degenerative process or the end-stage in the series of cell divisions. Within recent years considerable evidence has been presented which indicates that it may be a normal generative process.

The following tabulation of the literature indicates the adherents to the various theories advaneed. 
1. Amitosis occurs in highly specialized cells and is followed by degeneration:

Chun ('90) cited by Ziegler.

Flemming ('91), '92). In wandering cells which are on road to ruin.

Von Rath ('91, '93). In spermatozoa.

Ziegler ('91). In intense secretory cells.

Toyoma ('94). In the testes of the silkworm.

Krompeeher ('95). In bone-marrow.

Wilcox ('95). In giant spermatozoa "really come to naught."

Plate ('98). In dying cells of tracheal epithelium of Janelles.

deBruyne ('99). In ovarian follicle of Hemiptera and Orthoptera.

Wilson ('00). A secondary process in most cases.

Gross ('01). In germ cells of thirteen species of Hemiptera.

Payne ('12). In Gelastocoris, the cells which apparently multiply by amitosis do not produce ova.

2. Generative amitosis does occur and it is a normal method:

Arnold ('83-'84) Bone-marrow cells and leucocytes.

Löwit ('91) In leucocytes.

Verson ('91) In blind end of testicular follicle of Bombyx.

Frenzel ('G1) In intestinal glands of crayfish.

Paladino ('93, '95) The new formations of the placenta in mammals.

Reguard ('00) In Sertoli cells and spermatogonia of rats.

Camaniti ('03). In liver cells (as important as mitosis).

Hargitt ('03). In hydroids.

Klemensiewicz (03, '04.) In blood cells (as important as mitosis).

Child ('04). In the developing tissues of Moniezia.

Gurwitsch ('04).

Maximow ('08). Normal in mesenchyme cells of young dog embryo.

Glasser ('08). In entoderm of Fasciolaria (during development he found mitosis in 13 per cent and amitosis 87 per cent).

Rubaschkin ('08). In mesenchyme of embryo in region where gonads later form.

Foot and Strobell ('11). In ovaries of Protenor. Cells become ova.

Descilleuls ('14). In epithelial cells of viterine cornea.

Arber ('14). In cortical cells of root of Stratiotes.

McLean, ('14). In cortical parenchyma of aquatic angiosperms.

Jordan ('13). In ciliated cells.

3. Cells may divide by amitosis due to external conditions and later divide by mitosis again:

Meves ('91, '94, '96). In spermatogonia of salmandra. Due to cold.

Nathanson ('00). In plants external condition ether).

Gerasimoff ('92). In Spirogyra (says nothing of their return to mitosis). 
Preusse ('95). Ogonia of Hemiptera.

Pfeffer ('99). In Spirogyra.

MoGregor ('99). In Amphiuma.

Wasielewski ('03, '04). In root tip of Vicia.

Patterson ('08). In pigeon's blastoderm.

Wieman ('10). In ovaries and testes of Leptinotarsa.

Jordan ('13). In onion root.

4. Occurs in regions of rapid growth where the demand for certain foods exceeds the supply. The nucleus in such a condition is not in the proper equilibrium to divide by mitosis and so resorts to the easier method of amitosis.

Osborn ('04). In food ova of Fasciolaria.

Child ('07). In both invertebrates and vertebrates.

Patterson ('08). In pigeon's blastoderm (due to special physiological conditions.)

Wieman ('10). In reproductive cells of Leptinotarsa (change in nutritive supply).

Glasser ('05). A demand for a greater nuclear surface.

Jordan ('19). In blood and bone-marrow cells of frog. Lack of nutritive supply due to high degree of specialization.

\section{Amitosis is a purely pathological phenomenon:}

Glasser ('07). Food ova of Fasciolaria.

Pacaut ('09). In epithelial cells of mammalian cornea.

6. Amitosis is due to external mechanical pressure:

Nowikoff ('08, '09, '10) In cartilage, sinew, and bone cells of the mouse embryo.

7. Amitosis is a nuclear matter only. The cytoplasm does not divide, thus giving rise to a multinuclear cell:

Heidenhain ('94).

Karpow ('04). Leucocytes an exception. (His work was on the epidermis of amphibians and epithelium of the urinary bladder of mammals.)

Schurhoff ('15). In Ranunculus.

Macklin ('16). In the chick embryo.

8. Amitosis is a normal method of division in vertebrates only:

Nakahara ('18) makes the following statement: "Amitosis . . . . is not a method of cell multiplication, nor a sign of degeneration or senescence of cells, but, whenever it occurs, it seems to indicate an intense activity in the vegetative functions of the cell." 
Besides the views expressed above there are those who claim that amitosis as observed in the above cases is not amitosis at all. They would call it pseudo-amitosis or simply a peculiar type of mitosis. We shall mention only a few of those who so discredit amitosis:

Hacker ('00). In eggs of cyclops.

His ('00). In roots of Listera and Orchis.

Hargitt ('06). In clava leptostyla.

Richards ('09). In oögenesis of Taenia.

Harman, Mary T. ('13). In sex-cells of Taenia teniaeformis.

Conklin ('17).

\section{DISCUSSION}

The present observations on bone cells throw no further light on theories 3 and 8 , while theories 1,5 , and 6 are negatively answered. The first part of theory 1 , however, must receive some attention. Bone cells are highly specialized cells, and it is probable that this specialization does influence amitosis. That these cells have entered a stage of degeneration is not supported by these studies. Macewen believes that bone cells may at any time give rise to osteoblasts, thus attributing to them a generative or regenerative importance.

Theory 6 , which states that amitosis is a mechanical pinching in two of the cells due to external pressure, was formulated by Nowikoff as a result of his observations on amitosis in cartilage, tendon, and bone. His two pictures of bone cells in his 1910 article on "Zur Frage nach der Bedeutung der Amitose" indeed appear to support his view. In my own preparations no such pictures were found. The only examples from which such a view could be forced are shown in figures 2,3 , and 4 . In figures 2 and 3 there is only a slight rarefication of cytoplasm, while the nucleus is distinetly constricted but without signs of external constriction. In-figure 4 the cytoplasm is constricted, but the nucleus is completely divided into two daughter nuclei. These observations give the impression that cytoplasmic constriction occurs as a normal process following nuclear division. In dividing cells in which the horseshoe-shaped nucleus occurs--which 
is by far the most common method, there is not the least indication of external pressure. The only place where this theory might apply is in the case of protoplasmic fragmentation; that is, protoplasmic masses, with or without small nuclear remains, isolated from the main cell and connected with it by only a narrow cytoplasmic process (figs. 2 and 8 and fig. 4 previous paper). In such cases the deposition of bone takes place more rapidly on certain surfaces of the cell than on other, thus causing the constriction.

In reference to the other theories, it should be said that bone cells always multiply by amitosis, and therefore these observations support theory 2. Theory 4 also finds support in these observations in that amitosis occurs in young and rapidly growing bone. The growth is so rapid that the $4-\mathrm{mm}$. parietal bone of a newborn rat is $9 \mathrm{~mm}$. in diameter at the age of fourteen days. In such rapidly growing tissue it is reasonable that the question of food supply may have considerable influence. Furthermore, in bone the individual cells are connected with the source of food supply by only narrow cytoplasmic processes, which channels may be insufficient to supply the entire cell. While such views seem reasonable, they by no means are final, since any statement regarding function will of necessity be theoretical, and the study of bone cells warrants no positive statement regarding the physiological reason for amitotic cell division.

In mitosis there is a mechanism, the centrosome, which is apparently directly concerned in cell division. Some would have this mechanism an indispensable factor in all cell division. They regard all other signs of cleavage as incomplete division. Thus, theory 7 admits that the nucleus may divide by amitosis, but that no cytoplasmic division occurs in such cases. The division of leucocytes however, has been suggested, by adherents, of this view, as an exception to the rule. On the other hand, there are those who hold that complete cell division does occur in amitosis. Jordan, in his paper on "Amitosis in the epididymis of the mouse," has shown that cytoplasmic division follows amitotic division of the nucleus. Those who have described amitosis for sex cells believe in cytoplasmic division after nuclear division. 
In unpublished observations on red blood cells of Necturus, Dr. W. S. Miller, of the University of Wisconsin, has found that these blood cells divide amitotically. This division concerns not only the nucleus, but the cytoplasm as well, thus giving rise to two distinct cells. Doctor Miller has been kind enough to allow me to study this material and verify his findings.

In the face of these findings, it is impossible to say that amitosis is a nuclear matter only. The observations on bone cells do not help us in solving this question. Since bone cells form a syncytium, the cytoplasm does not completely separate in the dividing cell. In reality the cytoplasm is continuous, but the constriction is so nearly complete that the cells are regarded as units. Those who believe that amitosis results in incomplete division will find support in the division of bone cells. It seems, however, that a tissue whose cells form a syncytium is not a fitting tissue on which to determine this phase of the question.

Leaving out all theoretical possibilities which these observations suggest, we can make the following assertions:

1. Amitosis occurs normally among bone cells.

2. Amitosis occurs in rapidly growing bone.

3. Bone cells in which amitosis occurs are specialized cells.

4. Bone cells apparently do not divide completely, but form a syncytium.

\section{TYPES OF AMITOSIS AND THE RÔLE OF THE CENTROSOMES}

M. Nowikoff says, "Some authors differentiate two types of amitosis. The first begins with an elongated nucleus, which later takes on a biscuit like form. The bridge between the two enlarged nuclear ends becomes finer and finer and finally tears completely. Amitosis of the second type results from the formation of a notch in the nuclear membrane, which becomes deeper and deeper and in this way pinches the nucleus into two halves." Wasielewski recognizes these two types.

The description of the first agrees with the dumb-bell type described above. Nowikoff claims that it is the only type found in bone and tendon cells. This does not correspond at all with my observations on bone, which show that by far the majority 
of the dividing nuclei have a horseshoe-shaped nucleus. Many of the cells which Nowikoff illustates and which he classifies as cells of the first type.really appear to belong to the horseshoe type. Nowikoff studied sections of bone, and that may have led to a misinterpretation of the shape of the nucleus. For example, a horseshoe-shaped nucleus when cut at right angles to the bars of the horseshoe, near or at the bend, appears dumb-bell shaped. Or, if it is cut at an angle of $45^{\circ}$ with the bars of the horseshoe, it will look like a slightly bent dumb-bell, as many of his illustrations show. Thus the many different forms depend on the plane of section. In cartilage he found so many different forms representing all stages between the first and second type that he concluded that no two distinct types existed.

This question, however, deserves a little further consideration. The dumb-bell and horseshoe types in bone are too distinct and constant to pass unnoticed. This distinction becomes all the more apparent when we note that the shape of the nucleus is definitely related to the position of the centrosomes.

In the literature on amitosis very little is said regarding the centrosome. Many believe that it is entirely absent in cells that divide by amitosis. Among them are Henneguy, Lenhossek, Zimmerman, Heidenhain, Fuchs, Joseph, and Jordan in ciliated cells, and others. Among those who have observed centrosomes in amitotically dividing cells are Meyes, Studnicka, Fischel, Eismond, Henry, Benda, Gurwitsch, Ach, Wallengren, Ikeda, Erhard, Maximow, Nowikoff, Saguchi, Jordan, and others.

The above list indicates that the centrosomes have been quite generally found in amitotically dividing cells. Whether these centrosomes are of any functional importance in amitosis is a question which is usually negatively regarded. Flemming and Maximow always find the centrosome close to the nuclear membrane and at the place where the constriction takes place. In his 1910 paper Nowikoff tries to support Maximow's view regarding the centrosomes. However, in figure 45 of his 1908 article he shows two centrosomes which lie one at each of the two enlarged ends of the dumb-bell-shaped nucleus. In that case the centrosomes certainly have moved apart just as they do 
in case of mitosis. Saguchi presents a similar moving apart of the centrosomes in his figure 49 , plate 3 . In this case the nucleus has not moved apart as far as the one shown by Nowikoff or the one in my figure 2. This incomplete polar movement of the centrosomes accounts for the shape of the nucleus.

In my observations on bone cells a definite relationship between position of the centrosomes and the shape of the nucleus could be established. In trying to correlate this observation with those of other observers and with the various theories on amitosis, it appeared that amitotic nuclear forms can be classified according to the functioning ability of the centrosomes. If it is true, as many believe, that a cell may divide amitotically and then return to the mitotic type of division, and if the centrosome is active in mitosis and inactive in amitosis, then it is not strange that intermediate stages of centrosomal activity should occur. Food conditions, specialization, or external stimuli may disturb the equilibrium of the nuclear chromatin while the centrosome remains functional, thus causing amitotic division, or these disturbing factors may impair the migrating power of the centrosomes; or finally they may paralyze the entire mechanism which is active in mitosis and thus cause amitotic division.

In view of these observations and considerations, the following classification of amitotic types seems warranted:

Type I. The nucleus is dumb-bell shaped. The centrosomes have moved apart and placed themselves one at each end of the elongated nucleus and apparently 'exert a pull on it' (text fig. 1 a).

The only difference between this type of amitosis and mitosis is the inability of the nuclear chromatin to rearrange itself. Examples of this type are shown in figures 2, 3, and 4 . The illustrations of Nowikoff and Saguchi referred to above belong under this type.

Type II. The nucleus is horseshoe shaped. The centrosomes do not move apart, but they still 'exert a pull' on the nucleus. In some cases the movement of the nucleus around the centrosomes progresses to such an extent that the ends of the nucleus meet, thus forming a ring around the centrosomes (text figure $1,+b)$. 
This type is well represented in bone cells by figures 5 to 12 . Jordan describes this type in the blood and the bone-marrow of the frog and in the bone-marrow of the rabbit. Flemming's figure 5 is of this type. Most of Nowikoff's and Maximow's figures look as though they belonged to this type. Thus Maximow's figure 9 shows a nucleus which looks dumb-bell-like in shape. A comparison of this nucleus with the middle nucleus of my figure 10, which is a horseshoe-shaped nucleus viewed from one end, makes the similarity very apparent. Some of Arnold's



$a$

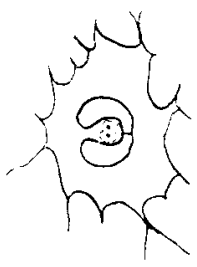

$b$

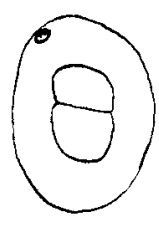

$\mathcal{C}$

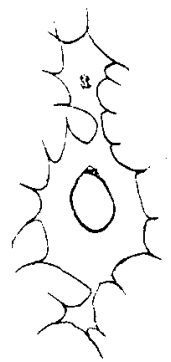

d

Text fig. 1 Diagrammatic sketches representing the four types of amitotic nuclear division. a, Type 1 . The nucleus is dumbbell-shaped with the centrosomes at the poles of the dividing nucleus. b, Type 2 . The nucleus is horseshoeshaped with the centrosomes within the bend of the nucleus. c, Type 3 . A plate like structure marks the plane of division of the oval-shaped nucleus. Centrosomes are near the surface of the cells, but they may be found in other positions or may be entirely absent. $d$, Cell fragmentation. The mass of protoplasm on top contains a small amount of unorganized nucleoplasm. The mass at the bottom contains no nuclear material.

observations belong here. Heidenhain has given the most extended list of descriptions and illustrations of this type.

Type III. In this type the centrosome is functionless; it neither moves apart nor exerts any influence on the nucleus. In some cases the centrosomes may be absent. In the early stages of division a plate-like structure marks the plane of cleavage (text fig. 1, c). A narrow notch on one surface of the nucleus often initiates separation of the daughter nuclei. The ciliated cells illustrated by Jordan and Saguhci and the fat cell by Nakahara belong to this type. I have found many nuclei 
of this type in smooth muscle cells of the human uterus (text fig. 2, a, b, c, and d). Such cases are also quite common among lymphocytes. ${ }^{1}$

\section{CELL FRIGMENTATION}

There are cases of unequal division which in reality are not true cell division, but only types of cell fragmentation (text fig. 1, d). Nowikoff found such cases in tendon and bone cells. He decided that such division was due to external pressure.
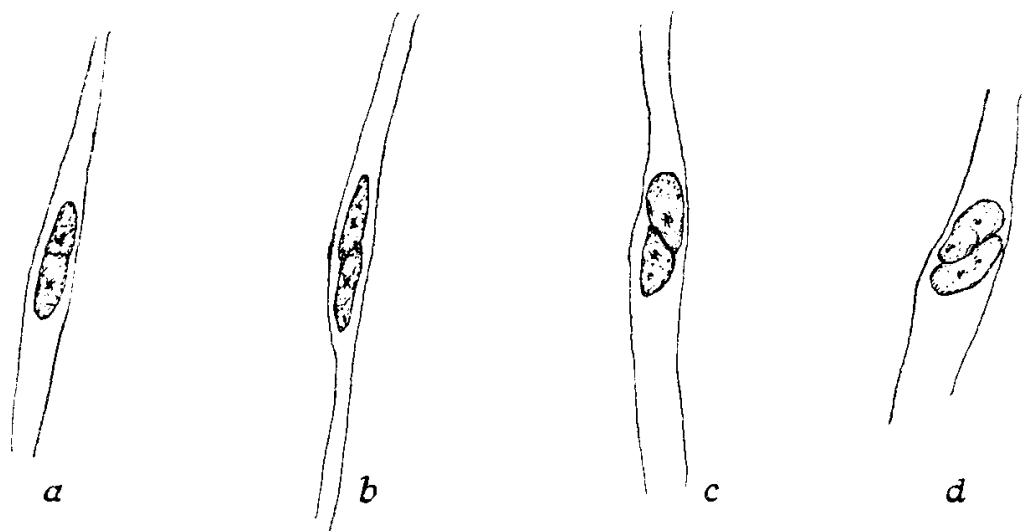

Text fig. 2 Camera-lucida drawings of smooth muscle cells from a pregnant human uterus. a, b, c and d show different forms of the third type of amitotic division. Original drawings were made on the scale of $\times 1200$, but were reduced in reproduction to $\frac{5}{3}$ of the original.

Maximow found them in mesenchymal tissue. The large masses of bone-cell protoplasm with or without nuclear fragments which I have found in bone (fig. 2, also fig. 4 of previous paper) belong to this type.

${ }_{1}$ Dr. C. H. Bunting, of the Pathological Laboratory of the University of Wisconsin, called my attention to this type of division among lymphocytes. 


\section{SUMMARY}

1. Bone cells divide by amitosis.

2. Division is more rapid in very young than in older bone.

3. Cell division seems to be a periodic process. In a given area all of the cells are in practically the same stage of division.

4. Amitosis is the normal method of bone-cell multiplication. That amitosis occurs rather than mitosis may be due to one or all of the following factors. a) High degree of specialization of cells concerned. b) Disturbance of nutritive equilibrium. c) Insufficient nuclear surface for the proper metabolic functioning of the cell.

5. Three types of amitosis are present in bone-cell division, and they are determined by the activity and position of the centrosomes. In one type the nucleus is dumb-bell shaped and the centrosomes are placed at the opposite poles of the nucleus. In the second type the centrosomes are placed in the center of the horseshoe-shaped nucleus. The latter type can hardly be considered as amitosis, but should be regarded as cell fragmentation. In this latter case division seems to be entirely due to external pressure.

6. A correlation of the various accounts of amitosis shows that one other type of amitosis exists. In this type the centrosomes are in no way concerned in the process of division. Centrosomes, as such, may or may not be present. A plate-like structure indicates the plane of division. 


\section{BIBLIOGRAPHY}

Arnold, J. 1883 Beobachtungen über Kerne und Kerntheilungen in den Zellen des Knochenmarks. Virch. Arch., Bd. 93, S.1.

1884 Weitere Beobachtungen über die Theilungsforgänge an den Knochenmarkzellen und weissen Blutkörpen. Virch. Arch,, Bd. 97.

BAST, T. H. 1921 Studies on the structure and multiplication of bone cells, facilitated by a new technique. Am. Journ. Anat., vol. 29, no. 2.

Chrld, C. M. 1907 a Amitosis as a factor in normal and regulatory growth. Anat. Anz., Bd. 30, No. 1 and 12.

$1907 \mathrm{~b}$ Studies on the relation of amitosis and mitosis. Biol. Bull., vol. 12 , nos. 2,3 , and 4 .

Flemming, W. 1891 Attraktionssphären und Centralkörper in Gewebszellen und Wanderzellen. Anat. Anz., Bd. 6, S. 78.

Heidenhain, M. 1894 Neue Untersuchungen über die Centralkörper und ihre Beziehungen zum Kern-und Zellenprotoplasma. Arch. f. mikro. Anat., $\mathrm{Bd} .43, \mathrm{~S} .423$.

Jordan, H. E. 1913 a Amitosis in the epididymis of the mouse. Anat. Anz., Bd. 44, 598.

$1913 \mathrm{~b}$ Experimental amitosis in onion root tip. Trans. of the Am. Microsc. Society, vol. 32 , no. 2.

1919 The histology of the blood and red bone marrow of the leopard frog, Rana pipiens. Am. Jour. Anat., vol. 25, p. 437.

1920 Further studies on red bone-marrow. Am. Jour. Anat., vol. 27, p. 287.

Macewen, W. 1912 J. Maclehose \& Son, Glasgow. The growth of bone.

Maximow, A. 1908 Uber Amitose in den embryonalen Geweben bei Säugetieren. Anat. Anz., Bd. 33, S. 89.

Nakahara, W. 1918 Studies of amitosis. Jour. Morph., vol. 30, p. 483.

Nowikoff, M. 1908 Beobachtungen über die Vermehrung der Knorpelzellen nebst einigen Bemerkungen über die Structur der 'hyalinen' Knorpelgrundsubstanz. Zeitsch. f. wissensch. Zool., Bd. 90.

1909 Untersuchungen über die Struktur des Knochens. Zeitsch. f. wissenseh. Zool., Bd. 92.

1910 Zur Frage nach der Bedeutung der Amitose. Arch. f. Zellforsch., Bd. 5, S. 365 .

Rubaschkin 1908 Zur Frage von der Entstehung der Keimzellen bei Säugetierembryonen. Anat. Anz., Bd. 32.

SAGUChI, S. 1917 Studies on ciliated cells. Jour. Morph., vol. 29, p. 217.

For a more extended bibliography on amitosis see Saguchi and Nakahara, referred to above. 


\section{PIATE 1}

\section{EXPLANATION OF FIGURES}

All of these drawings are camera-lucida drawings of cells from the entire parietal bones of young rats, except figures 3,4 , and 5 , which were taken from the ethmoid bone of a dog. These bones were fixed in 95 per cent alcohol and stained in gentian violet. The original magnification as indicated for each figure was reduced: in reproduction.

1 Normal bone cell from fifteen day-old rat. The nucleus is oval in shape. $\times 1200$

2 Cell in early stage of division. Nucleus dumbbell shaped. Centrosomes at opposite poles of nucleus. Two large masses of protoplasm almost separated from main cell. $\times 1200$.

3 Cell from ethmoid bone of dog. A little later stage of nuclear division than figure 2. Cytoplasm is not constricted. $\times 1450$.

4 Cell from ethmoid bone of dog. Nucleus completely divided. Cytoplasm constricted. Centrosomes are faintly seen, but the centrioles are not visible. $\times 1450$.

5 Cell from the ethmoid bone of a dog. Early stage in the horseshoe type of amitosis. The centrosomes are placed at the center of the horseshoe-shaped nucleus. $\times 1450$.

6 The horseshoe-shaped nucleus has just divided. Centrosomes at the center. $\times 1600$.

7 A later stage in the division of a horseshoe-shaped nucleus. The two daughter nuclei are kidney shaped and only slightly separated. The centrosomes are four in number and still centrally placed. $\times 1600$.

8 Late stage in the horseshoe type of amitosis. The cytoplasm is deeply constricted. The irregular shaped nuclei are due to improper fixation. $\times 1450$.

9 These three nuclei are the product of the division of a horseshoe-shaped nucleus. Centrosomes centrally placed. $\times 1600$.

10 Three cells derived from a cell with a horseshoe-shaped nucleus. The nuclei of these cells are already in the early stage of division. $\times 1450$.

11 Pentanucleated cell with the nuclei still arranged in the shape of a horseshoe. Multicorpuscular centrosome within ring of nuclei. $\times 1600$.

12 Four cells which are probably the product of a tetranucleated cell. Note the large protoplasmic connections. $\times 1600$. 




